\title{
Lonomia obliqua Walker (Lepidoptera: Saturniidae): hemostasis implications
}

\author{
Silviane Maggi ${ }^{1 *}$, Gustavo Adolpho Moreira Faulhaber ${ }^{2}$ \\ ${ }^{1}$ Pharmacist and biochemistry from the Universidade de Caxias do Sul (UCS). Specialist in Clinical Analysis, Hematology and Hemotherapy at Universidade Feevale, Novo Hamburgo. Master's student in Biotechnology \\ from UCS, Caxias do Sul, RS, Brazil \\ ${ }^{2}$ Associate Professor, Department of Internal Medicine of the Universidade Federal do Rio Grande do Sul (UFRGS), Porto Alegre, RS, Brazi
}

\begin{abstract}
SUMMARY
Study conducted at Universidade Feevale,

Novo Hamburgo, RS, Brazil

Article received: 6/6/2014 Accepted for publication: 6/15/2014

*Correspondence: Address: ERS 239, 2755 Novo Hamburgo, RS - Brazil Postal code: 93352-000 silvianem@yahoo.com.br smaggi@ucs.br

In southern Brazil, since 1989, several cases of accidents produced by unwilling contact with the body of poisonous caterpillars of the moth species Lonomia obliqua Walker, 1855 (Lepidoptera: Saturniidae), were described. L. obliqua caterpillars have gregarious behavior and feed on leaves of host trees during the night, staying grouped in the trunk during the day, which favors the occurrence of accidents with the species. This caterpillar has the body covered with bristles that on contact with the skin of individuals, breaks and release their contents, inoculating the venom into the victim. The basic constitution of the venom is protein and its components produce physiological changes in the victim, which include disturbances in hemostasis. Hemorrhagic syndrome associated with consumption coagulopathy, intravascular hemolysis and acute renal failure are some of the possible clinical manifestations related to poisoning by L. obliqua. Specific laboratory tests for diagnosis of poisoning have not been described previously. The diagnosis of poisoning is made based on the patient's medical history, clinical manifestations, erythrocyte levels, and, primarily, parameters that evaluate blood coagulation. Treatment is performed with the use of supportive care and the administration of specific hyperimmune antivenom. Poisoning can be serious and even fatal.
\end{abstract}

http://dx.doi.org/10.1590/1806-9282.61.03.263

Conflict of interest: none
Keywords: hemostasis, Lepidoptera, animals, poisonous.

\section{INTRODUCTION}

Brazil is a country with wide biodiversity, with many living organisms oblivious to human contact, sometimes remaining unknown in nature. Factors related to anthropological issues end up favoring contact between human beings and such organisms at some point, including deforestation, expansion of urban areas, tourism and more. In this context, the properties of these animals, plants and microorganisms have an opportunity to become known.

This may be the case of a moth caterpillar of the genus Lonomia. In 1969, Arocha-Piñango and Layrisse ${ }^{1}$ reported fibrinolytic hemorrhagic diathesis in individuals who had contact with bristles of caterpillars of the Saturniidae family, in Venezuela. In Brazil, since 1989, a high incidence of hemorrhagic syndrome has been reported in rural areas of the states of Rio Grande do Sul and Santa Catarina, and some cases have been reported in the state of Paraná. Accidental contact with caterpillars found on trees has been implied as the cause. ${ }^{2}$ Poisoning by caterpillars causing bleeding disorders has also been described in French Guiana. ${ }^{3}$

The species involved in the accidents report in Venezuela and French Guiana was identified as Lonomia achelous Cramer, ${ }^{1,3}$ while in Brazil, poisoning was attributed to Lonomia obliqua Walker, 1855 . $^{2}$

Both species belong to the genus Lonomia, of the Saturniidae family, Hemileucinae subfamily, the Insect class and Lepidoptera order. Lepidoptera are represented by butterflies, with diurnal habits, and moths, which are nocturnal.

Serious and even fatal accidents have been reported as a result of accidental contact with the larval form, or caterpillar, of moths from the genus Lonomia. ${ }^{4-9}$ At this stage of development, the caterpillars stay together in groups on the trunk of host trees during the day, moving toward the end of the branches to feed on the leaves at night. ${ }^{10}$ This behavior favors the occurrence of acci- 
dents due to proximity to the ground and the fact that they remain grouped, which is also related to the severity of the poisoning, since the number of animals involved may be high.

Removal of the plant coverage related to deforestation, replacement of native forests by monoculture of large areas, using pesticides and reduction of natural predators contribute to ecological imbalance. The latter may be implicated as a justification for the increasing population of these caterpillars in locations different from their original ones, which can favor the occurrence of accidents with humans. ${ }^{2,11}$

\section{Clinical symptoms}

In poisoning caused by $L$. achelous Cramer, the symptoms described began with pain, with a burning sensation at the site of contact with the insects, followed by widespread pain and discomfort, and occipital headache. Extensive ecchymosis was observed in the contact region between 8 and 72 hours after the accident, as well as bleeding in different places such as the nose, ears, intestines, vagina and skin. ${ }^{12}$

The hemorrhagic syndrome that develops after contact with the caterpillars was characterized by having low levels of fibrinogen, plasminogen, factor V and factor VIII, increased factor VIII:C, von Willebrand factor and fibrinogen degradation products (FDP). Other factors and coagulation inhibitors were normal, as well as the platelet count. ${ }^{12}$ Furthermore, a short euglobulin lysis time was verified alongside lower concentrations of fibrinogen, and a normal platelet count, suggesting intense fibrinolytic activity. ${ }^{1}$

A study conducted by Guerrero and Arocha-Piñango ${ }^{13}$ reported the presence of factor VIII inhibitor in the venom of L. achelous. Subsequently, Guerrero et al. ${ }^{14}$ observed that the hemolymph of $L$. achelous or chromatographic fractions of it caused the activity of factor XIII to decrease in a dose-dependent manner in human or rabbit plasma. The investigations that followed identified a serine protease called Lonomin $\mathrm{V}$ as responsible for the inactivation of factor XIII from different origins, with proteolytic activity on fibrin, fibrinogen and factor XIII being described. ${ }^{15}$

When poisoning is caused by the caterpillars of the species L. obliqua, the signs and symptoms described after contact with the bristles consisted of pain and a burning sensation, redness and swelling at the contact site, general malaise, vomiting, shortness of breath, bruising, bleeding of mucous membranes and of recent scars, epistaxis, melena, hematuria, anuria, hypotension, headache, arthralgia, myalgia, back pain, weakness, and fever. $2,5,7,8,16-18$
At a physiological level, the action of the venom produces a series of events that lead to disruption of hemostasis, with consequences that may develop in a serious or even fatal manner. The conditions observed in this type of accident include a characteristic hemorrhagic syndrome triggered by consumption coagulopathy, which can progress to decreased blood pressure, edema and erythema, and intravascular hemolysis.

Acute renal failure is often observed, along with pulmonary hemorrhage and intracerebral hemorrhage, as manifestations of greater severity and risk reported in patients injured by L. obliqua. ${ }^{2,4,16,17,19}$ In the most serious cases, the progression of poisoning symptoms led to death. ${ }^{2,4,17,19}$

In a study conducted by Burdmann et al., ${ }^{18}$ discrete changes associated mostly with ischemic injury rather than nephrotoxicity were found by renal biopsy after poisoning by L. obliqua. The syndrome occurring during poisoning, similar to disseminated intravascular coagulation, can produce massive fibrin deposition in the glomeruli and be involved in the development of acute renal failure (ARF). On the other hand, Fan et al. ${ }^{5}$ suggested that acute tubular necrosis resulting from hemorrhagic shock would be a possible cause of ARF.

In patients that develop ARF, there was a mortality rate of $50 \%$ ( 3 out of 6 patients, 2 by cerebral hemorrhage and 1 by massive pulmonary hemorrhage), while among those with preserved renal function, mortality was at $4 \%$ ( 1 out of 27 patients). ${ }^{17}$

ARF is not observed in all patients, but can occur in people of any age and the factors that contribute to its development remain unknown. There are also reports of ARF occurring in children. ${ }^{20}$

The hemorrhagic syndrome was not reproduced in mice and guinea pigs, but in rats one hour after contact with the caterpillars, blood became incoagulable and hematuria was observed, as it occurs in human poisonings. ${ }^{2}$

A common finding in patients with this type of poisoning is blood coagulation followed by depletion of fibrinogen, which was attributed to the presence of factor $\mathrm{X}$ and prothrombin activators in the venom. The thrombin may be produced directly or by activation of factor $\mathrm{Xa}$, and is responsible for cleavage of fibrinogen, factor $\mathrm{V}$ and factor XIII, which is the form in which these factors are consumed. ${ }^{21}$

The consumption coagulopathy observed is most often severe and is often characterized by the production of high levels of prothrombin fragments, the formation of thrombin-antithrombin complexes and D-dimers in addition to the depletion of fibrinogen. Nevertheless, the number of platelets is normal or has a slight reduction, while antithrombin concentration is also modestly lower. ${ }^{22}$ 
As for platelet assessment, functional impairment was identified with hypoaggregation in vivo. Disorders of blood coagulation have been demonstrated after poisoning induced in rats, but the effect on platelets was produced by intravascular generation of nitric oxide and fibrin and fibrinogen degradation products rather than the venom's direct action. ${ }^{23}$

On the other hand, in vitro, the aggregation and adhesion of human platelets has been induced by the action of an extract from the caterpillar bristles, where it was observed that aggregation occurs in a dose-dependent manner and concurrently with the reaction for releasing adenosine triphosphate (ATP). ${ }^{24}$

Fritzen et al. ${ }^{25}$ studied the action of an isolated protein present in the caterpillar venom, which produced an increase in the release of the molecules involved in regulating vascular tone, inhibiting platelet activation and chemotaxis through direct effect on endothelial cells.

Diffuse bleeding areas on the skin have also been observed in accidents involving L. obliqua and were related to the depletion of fibrinogen and/or platelet aggregation inhibition..$^{25}$

The kallikrein-kinin system has also been described as subject to the action of the venom. The release of kinins from all the kininogens was attributed to this action and can occur directly, by low molecular weight kininogen, and indirectly, through plasma prekallikrein activation from high molecular weight kininogen. In this way, decreased blood pressure can be observed, with the appearance of erythema and edema related to the effects of the venom on this system. ${ }^{26}$

In a study conducted by Seibert et al. ${ }^{27}$ with the extract of L. obliqua bristles, the induction of direct and indirect hemolytic activity on human red blood cells and those of rats were shown in vitro. Subsequently, in an in vivo study, rats were experimentally poisoned using the extract of bristles and intravascular hemolysis was observed after 1 hour, peaking at 6 hours. Increase in the reticulocyte count, increase in plasma hemoglobin levels, and decrease in plasma haptoglobin levels were observed. ${ }^{28}$

At that time, reports of the occurrence of intravascular hemolysis in humans accidentally poisoned had not been encountered, until described in the work of Malaque et al. Intravascular hemolysis observed in humans showed low plasma levels of haptoglobin, high free hemoglobin levels, high serum levels of LDH (lactate dehydrogenase) and increased serum levels of unconjugated bilirubin. ${ }^{7}$

\section{LABORATORY TESTS}

When responding to accidents involving L. obliqua caterpillars, a variety of laboratory parameters were evaluated in order to investigate the cause of the signs and symptoms, if unknown, and to provide appropriate support measures and treatment.

The parameters described include reports of prolonged thrombin time (TT), prothrombin time (PT) and activated partial thromboplastin time (aPTT), slightly reduced platelet counts, hypofibrinogenemia, low hemoglobin and leukocytosis. An increase in the levels of creatinine, urea and serum potassium was also cited. Furthermore, elevations were observed in aspartate aminotransferase, alanine aminotransferase, total bilirubin and direct bilirubin., ${ }^{2,5,16-18}$

\section{Clinical management of poisoning}

With a significant record of cases of accidents with caterpillars belonging to this species in southern Brazil since 1989, including the occurrence of deaths as a result, in 1994, researchers at the Butantan Institute (São Paulo, Brazil) started the production of a specific hyperimmune serum for the treatment of poisoning by L. obliqua. This serum is obtained by purification of a solution of specific immunoglobulins derived from equine hyperimmunization with the extract of L. obliqua bristles and was called antilonomic serum (SALon)..$^{29,30}$

Previously and as an alternative to the use of serum, antifibrinolytic drugs such as epsilon-amino-caproic acid (EACA) and transfusion of concentrated red blood cells, fresh frozen plasma and cryoprecipitate has been described in the replacement of coagulation factors and management of significant blood loss. ${ }^{2,4,16}$

In rats experimentally poisoned with the venom of $L$. obliqua caterpillars, the use of EACA produced high mortality rates, suggesting that this therapeutic approach is not suitable for humans suffering accidents involving this species, despite being recommended in poisoning involving the species $L$. achelous. ${ }^{31,32}$

The use of antilonomic serum was effective in preventing the death of poisoned individuals and enabled faster restoration of coagulation parameters affected by venom compared to individuals not treated with antivenoms. ${ }^{33}$ Despite the advantages of its use, susceptible individuals may develop adverse reactions related to the administration of heterologous equine antivenom, which are in turn related to the amount of protein infused, dilution rate and the speed of administration. ${ }^{34}$

\section{Composition of the venom}

In order to investigate the compounds involved in the actions of the poison, several studies have been conducted and mechanisms of action have been proposed, although many of the activities observed still require further investigation. 
The majority of the venom of L. obliqua caterpillars is constituted of proteins and peptides. In the crude extract of L. obliqua caterpillar bristles there are protease inhibitors, serine protease and lipocalins. A minor presence of metalloproteinases, lecithins and phospholipase was also identified. On the other hand, the hemolymph showed a similar protein constitution, but in different proportions. ${ }^{35}$

Donato et al. ${ }^{21}$ reported on the property of the caterpillar bristle extract to activate prothrombin dependent on calcium ions. Afterwards, a protein was isolated from it, which was named Lonomia obliqua prothrombin activator protease (Lopap), and to which said property was attributed. This protein consists of a tetramer characterized by a molecular mass of $69 \mathrm{kDa}$ in its native form and which presents serine protease type activity, activated by calcium ions. ${ }^{36}$

Lopap did not display a partial sequence of amino acids in the purified protein similar to any other known prothrombin activator. ${ }^{36}$ Despite this lack of similarity with other known activators of prothrombin or serine proteases, this protein has conserved domains in the primary sequence characteristic of lipocalins, and the secondary and tertiary structures have a pattern similar to the proteins of this family. ${ }^{37}$

Intense consumption coagulopathy after accidental contact with the caterpillar's bristles has been linked to the action of Lopap, which has also been observed in rats when infused with the purified protein. ${ }^{38}$

Lopap has been classified as a type 4 prothrombin activator, although being an exception within this group since, unlike the other members of this class, it is capable of producing active thrombin. ${ }^{36}$ It has been shown that this protein has pro-coagulant activity in rats and, in its purified form, is capable of activating prothrombin in a dose dependent manner, with calcium ions increasing this activity. ${ }^{36,39}$

In a study by Fritzen et al., ${ }^{25}$ Lopap significantly increased the production of nitric oxide (NO), triggered the release of prostacyclin-1 (PGI2) and Interleukin-8 (IL-8), but was not capable of modulating the expression of mediators involved in coagulation and fibrinolysis system, or to induce the release of von Willebrand factor or its synthesis by endothelial cells and modulation of tissue factor (TF) and tissue plasminogen activator ( $\mathrm{t}-\mathrm{PA})$. The authors also reported the action of the protein promoting cell survival by regulating the expression of NO. Increased levels of NO were also observed during the experimental poisoning of rats. ${ }^{24}$

Recently, it has been reported that lipocalin present in L. obliqua may act by modulating fibroblasts and the extracellular matrix, which may be related to its action on morphogenesis and tissue homeostasis. ${ }^{40}$
Alvarez-Flores et al. ${ }^{41}$ identified another protein in the extract of L. obliqua bristles, named by them Lonomia obliqua stuart-factor activator (Losac). It has procoagulant action, activating coagulation factor $\mathrm{X}$, independently from calcium ions. This protein, which is classified as a hemolin, was also able to trigger the release of NO, but not PGI2 in human umbilical vein endothelial cells (Huvec). Losac was also attributed the property of stimulating the growth and inhibiting the death of endothelial cells. ${ }^{42}$

Campos and Dias-da-Silva ${ }^{43}$ identified the activity of phospholipase A2 (PLA2) in the extract of L. obliqua bristles. The phospholipase in question is an extracellular enzyme of $15 \mathrm{kDa}$ and its activity is dependent on the presence of a phospholipid (lecithin) substrate and $\mathrm{Ca}^{++} .2$ In washed rat and human erythrocytes, this phospholipase showed similar indirect hemolytic activity. ${ }^{27}$

Berger et al. ${ }^{24}$ demonstrated that the venom of L. obliqua is capable of producing platelet aggregation in humans through a calcium-dependent mechanism involving arachidonic acid metabolites from the cyclooxygenase pathway and activation of phosphodiesterase 3A (PDE3A). This probably results in consumption of the intracellular cyclic adenosine monophosphate content (cAMP). Phospholipase $\mathrm{A} 2$ present in the venom has been implicated as the main component responsible for this activity.

Fibrinolytic enzymes capable of cleaving fibrinogen and fibrin have been identified in the venom of L.obliqua. Lonofibrase has been described among them, which is a fibrinogenolytic enzyme of $35 \mathrm{kDa}$, involved in the rapid and selective degradation of fibrinogen $\alpha$ chains and, with less efficiency, $\beta$. Furthermore, Lonofibrase presents a fibrin cleaving capacity different to that observed with plasmin, suggesting different mechanisms of action. ${ }^{44}$

\section{Conclusion}

Most accidents with humans involve a relatively small amount of inoculated venom. Thus, possible indirect effects produced from a cellular response to the venom components should be considered. The increased regulation of several genes could cause this response leading to the activation and migration of inflammatory cells, degradation of plasma proteins and of the extracellular matrix, and increased procoagulant activity in the plasma of patients. Furthermore, such genes could participate in the inflammation, edema and pain observed in poisoned patients, as well as amplification of the activation of the fibrinolytic system, and disseminated intravascular coagulation. ${ }^{45}$

To date, specific laboratory tests have not been described, and the clinical manifestations that lead the vic- 
tim to seek medical attention may take time to appear, preventing accurate diagnosis and appropriate clinical management at times. Therefore, knowledge of physiological events of hemostasis and their interrelations is indispensable so that proper treatment can be given by the health professionals involved in the care of individuals poisoned by L. obliqua caterpillars.

The mechanisms through which L. obliqua venom produces effects on hemostasis have not been fully clarified. Thus, more studies in this respect are required.

\section{Resumo}

Lonomia obliqua Walker (Lepidoptera: Saturniidae): implicações em hemostasia.

Na região Sul do Brasil, a partir de 1989, foram descritos inúmeros casos de contato acidental com o corpo de lagartas venenosas da mariposa da espécie Lonomia obliqua Walker, 1855 (Lepidoptera: Saturniidae). As lagartas de $L$. obliqua possuem comportamento gregário e alimentam-se de folhas das árvores hospedeiras durante a noite, permanecendo agrupadas no tronco durante o dia, o que favorece a ocorrência de acidentes. Essa lagarta possui o corpo recoberto por cerdas urticantes, que, ao contato com a pele dos indivíduos, se rompem e liberam seu conteúdo, inoculando o veneno na vítima. A constituição básica do veneno é proteica e seus componentes produzem modificações fisiológicas no acidentado, que incluem distúrbios na hemostasia. Síndrome hemorrágica associada a coagulopatia de consumo, hemólise intravascular e insuficiência renal aguda são algumas das manifestações clínicas possíveis relacionadas ao envenenamento por $L$. obliqua. Ainda não foram descritas avaliações laboratoriais específicas para diagnóstico do envenenamento, que é feito com base na anamnese do paciente, nas manifestações clínicas, nos índices hematimétricos e, principalmente, nos parâmetros que avaliam a coagulação sanguínea. A terapêutica é feita com a utilização de medidas de suporte e com a administração de um soro heterólogo hiperimune específico. Os envenenamentos podem ser graves e até mesmo fatais.

Palavras-chave: hemostasia, lepidópteros, animais venenosos.

\section{References}

1. Arocha-Piñango CL, Layrisse M. Fibrinolysis produced by contact with a caterpillar. Lancet.1969; 1(7599):810-12.
2. Kelen EMA, Picarelli ZP, Duarte AC. Hemorrhagic syndrome induced by contact with caterpillars of the genus Lonomia (Saturniidae, Hemileucinae) J Toxicol Toxin Rev. 1995; 14(3):283-308

3. Hommel D, Bouchareine L, Hulin A. Acute-poisoning by the caterpillar Lonomia achelous. Review of the literature. Report of 2 cases in French Guyana. Sem Hop. 1995; 71(1):9-12.

4. Duarte AC, Crusius PS, Pires CAL, Schilling MA, Fan HW. Intracerebral haemorrhage after contact with Lonomia caterpillars. Lancet. 1996; 348(12):1033.

5. Fan HW, Cardoso JLC, Olmos RD, Almeida FJ, Viana RP, Martinez APP. Hemorrhagic syndrome and acute renal failure in a pregnant woman after contact with Lonomia caterpillars: a case report. Rev Inst Med Trop São Paulo. 1998; 40(2):119-20.

6. Gamborgi GP, Metcalf EB, Barros EJG. Acute renal failure provoked by toxin from caterpillars of the species Lonomia obliqua. Toxicon. 2006; 47(1):6874.

7. Malaque CMS, Andrade L, Madalosso G, Tomy S, Tavares FL, Seguro AC. Short report: a case of hemolysis resulting from contact with a Lonomia caterpillar in southern Brazil. Am J Trop Med Hyg. 2006; 74(5):807-9.

8. Riella MC, Chula D, Freitas S, Mazza M, Pachaly MA. Acute renal failure and haemorrhagic syndrome secondary to toxin of caterpillars (Lonomia obliqua). Nephrol Dial Transplant. 2008; 23(6):445-6.

9. Basualdo A, Oliveira KC, Trevisan T, Barletta FB. Tratamento clínico e bucomaxilofacial de quadro hemorrágico-alérgico por Lonomia sp: relato de caso. Stomatos. 2008; 24(14):46-54.

10. Lorini LM. A taturana: aspectos biológicos e morfológicos da Lonomia obliqua. Passo Fundo: EDIUPF, 1999

11. Moraes RHP. Identificação dos inimigos naturais de Lonomia obliqua Walker, 1855 (Lepidoptera, Saturniidae) e possíveis fatores determinantes do aumento de sua população. [Dissertation]. Piracicaba: Escola Superior de Agricultura Luiz de Queiroz, Universidade de São Paulo, 2002.

12. Marval E, Guerrero B, Arocha-Piñango CL. The action of the venom of the Lonomia achelous caterpillars on rabbit blood coagulation. Toxin. 1999; 31(11):1491-504.

13. Guerrero B, Arocha-Piñango CL. Factor VIII inhibitor in the venom of Lonomia achelous caterpillars. In: Abstracts of 12th INTNAT'L Congress, 1992.

14. Guerrero BAG, Arocha-Piñango CL, San Juan AG. Lonomia achelous caterpillar venom (LACV) selectively inactivates blood clotting factor VIII. Thromb Res. 1997; 87(1):83-93.

15. Guerrero B, Perales J, Gil A, Arocha-Piñango CL. Effect on platelet FXIII and partial characterization of Lonomin $\mathrm{V}$, a proteolytic enzyme from Lonomia achelous caterpillars. Thromb Res. 1999; 93(2):243-52.

16. Duarte AC, Caovilla J, Lorini I, Lorini D, Mantovani G, Sumida J, et al. Insuficiência renal aguda por acidentes com lagartas. J Bras Nefrol. 1990; 4(12):184-7.

17. Duarte A, Walter G, Barros E, Lorini I. Insuficiência renal aguda nos acidentes com Lonomia obliqua. Nefrol Lat Americana.1994; 1(1):38-40

18. Burdmann EA, Antunes I, Saldanha LB, Abdulkader RCMR. Severe acute renal failure induced by the venom of Lonomia caterpillars. Clin Nephrol. 1996; 46(5):337-9.

19. Kowacs PA, Cardoso J, Entres M, Novak EM, Werneck LC. Fatal intracerebral hemorrhage secondary to Lonomia obliqua caterpillar envenoming. Arq Neuropsiquiatr. 2006; 64(4):1030-2.

20. Bresolin N, Fernandes V, Carvalho F, Goes J, Araujo L, Simon M, et al. Acute renal failure (ARF) in a child after contact with caterpillars of the genus Lonomia obliqua: a case report. Pediatr Nephrol. 2007; 22(9):1551.

21. Donato JL, Moreno RA, Hyslop S, Duarte A, Antunes E, Le Bonniec BF, et al. Lonomia obliqua caterpillar spicules trigger human blood coagulation via activation of factor $\mathrm{X}$ and prothrombin. Thromb Haemost. 1998; 79(3):539-42

22. Zannin M, Lourenço DM, Dala Costa LR, Grando M, Gamborgi GP, Noguti MA, et al. Hemostatic disorder observed in patients affected by accidental contact with Lonomia obliqua caterpillar, Santa Catarina, south Brazil Thromb Haemost. 2003; 89(2):355-64.

23. Berger M, Reck Jr J, Terra RMS, Pinto AFM, Termignoni C, Guimarães JA. Lonomia obliqua caterpillar envenomation causes platelet hypoaggregation and blood incoagulability in rats. Toxicon. 2010; 55(1):33-44.

24. Berger M, Reck Jr J, Terra RMS, Silva WOB, Santi L, Pinto AFM, et al. Lonomia obliqua venomous secretion induces human platelet adhesion and aggregation. J Thromb Thrombolysis. 2010; 30(3):300-10. 
25. Fritzen M, Alvarez-Flores MP, Reis CV, Chudzinski-Tavassi AM. A prothrombin activator (Lopap) modulating inflammation, coagulation and cell survival mechanisms. Biochem Biophys Res Commun. 2005; 333(2):517-23.

26. Bohrer CB, Reck Jr. J, Fernandes D, Sordi R, Guimarães JA, Assreuy J, et al. Kallikrein-kinin system activation by Lonomia obliqua caterpillar bristles: Involvement in edema and hypotension responses to envenomation. Toxicon. 2007; 49(6):663-9.

27. Seibert CS, Shinohara EMG, Sano-Martins IS. In vitro hemolytic activity of Lonomia obliqua caterpillar bristle extract on human and Wistar rat erythrocytes. Toxicon. 2003; 41(8):831-9.

28. Seibert CS, Oliveira MRL, Gonçalves LRC, Santoro ML, Sano-Martins IS Intravascular hemolysis induced by Lonomia obliqua caterpillar bristle extract: an experimental model of envenomation in rats. Toxicon. 2004; 44(7):793-9.

29. Dias-da-Silva, W, Gonçalves LCR, Campos ACMR, Silva MCCS, Duarte AC Moraes RHP, et al. Anti-lonomia serum: an antivenom produced to neutralize the hemorrhagic disorder induced by a caterpillar toxin (Abstract). Toxicon 1996; 34(1):18

30. Dias-da-Silva W, Campos ACMR, Gonçalves LRC, Sousa-e-Silva MCC, Higashi HG, Yamagushi IK, et al. Development of an antivenom against toxins of Lonomia obliqua caterpillars. Toxicon. 1996; 34(9):1045-9.

31. Arocha-Piñango CL, De Bosch NB, Torres A, Goldstein C, Nouel A, Argüello A, et al. Six new cases of a caterpillar-induced bleeding syndrome. Thromb Haemost. 1992; 67(4):402-7.

32. Gonçalves LRC, Sousa-e-Silva MCC, Tomy SC, Sano-Martins IS. Efficacy serum therapy on the treatment of rats experimentally envenomed by bristle extract of the caterpillar Lonomia obliqua: comparison with epsilonaminocaproic acid therapy. Toxicon. 2007; 50(2):349-56.

33. Rocha-Campos ACM, Gonçalves LRC, Higashi HG, Yamagushi IK, Fernandes I, Oliveira JE, et al. Specific heterologus $\mathrm{F}\left(\mathrm{ab}^{\prime}\right) 2$ antibodies revert blood incoagulability resulting from envenoming by Lonomia obliqua caterpillars. Am J Trop Med Hyg 2001; 64(5-6):283-9.

34. Caovilla JJ, Barros EJG. Efficacy of two different doses of antilonomic serum in the resolution of hemorrhagic syndrome resulting from envenoming by Lonomia obliqua caterpillars: a randomized controlled trial. Toxicon. 2004; 43(7):811-8.
35. Terra RMS. Venômica: Identificação de proteínas envolvidas na fisiopatologia de envenenamentos animais. [Tese]. Porto Alegre: Centro de Biotecnologia, Universidade Federal do Rio Grande do Sul, 2010.

36. Reis CV, Portaro FCV, Andrade AS, Fritzen M, Fernandes BL, Sampaio CAM, et al. A prothrombin activator serine protease from the Lonomia obliqua caterpillar venom (Lopap) biochemical characterization. Thromb Res. 2001; 102(5):427-36.

37. Reis CV, Andrade SA, Ramos OHP, Ramos CRR, Ho PL, Batista IFC, et al. Lopap, a prothrombin activator from Lonomia obliqua belonging to the lipocalin family: recombinant production, biochemical characterization and structure-function insights. Biochem J. 2006; 398(2):295-302.

38. Chudzinski-Tavassi AM, Schattner M, Fritzen M, Pozner RG, Reis CV Lourenço D, et al. Effects of Lopap on human endothelial cells and platelets. Haemostasis. 2001; 31(3-6):257-65.

39. Reis CV, Kelen EMA, Farsky SHP, Portaro FCV, Sampaio CAM, Fernandes $\mathrm{BL}$, et al. A Ca++ activated serine protease (LOPAP) could be responsible for the haemorrhagic syndrome caused by the caterpillar Lonomia obliqua. L. obliqua prothrombim activator protease. Lancet. 1999; 353(9158):1942.

40. Carrijo-Carvalho LC, Maria DA, Ventura JS, Morais KLP, Melo RL, Rodrigues $\mathrm{CJ}$, et al. A lipocalin-derived peptide modulating fibroblasts and extracellular matrix proteins. J Toxicol. 2012; 2012:325250.

41. Alvarez-Flores MP, Furlin D, Ramos OHP, Balan A, Konno K, ChudzinskiTavassi AM. Losac, the first hemolin that exhibits procoagulant activity through selective factor x proteolytic activation. J Biol Chem. 2011; 286(9):6918-28.

42. Alvarez-Flores MP, Fritzen M, Reis CV, Chudzinski-Tavassi AM. Losac, a factor $\mathrm{X}$ activator from Lonomia obliqua bristle extract: Its role in the pathophysiological mechanisms and cell survival. Biochem Biophys Res Commun. 2006; 343(4):1216-23.

43. Campos ACMR, Dias-da-Silva W. Detection of a phospholipase-like activity, in the venom from Lonomia obliqua (Abstract). Toxicon.1996; 34(1):15.

44. Pinto AFM, Dobrovolski R, Veiga ABG, Guimarães JA. Lonofibrase, a novel $\alpha$-fibrinogenase from Lonomia obliqua caterpillars. Thromb Res. 2004; 113(2):147-54

45. Pinto AFM, Dragulev B, Guimarães JA, Fox JW. Novel perspectives on the pathogenesis of Lonomia obliqua caterpillar envenomation based on assessment of host response by gene expression analysis. Toxicon. 2008; 51(6):1119-28. 